\title{
MANAJEMEN PROGRAM KELAS TAHFIDH AL-QUR'AN DI MIN 2 SLEMAN YOGYAKARTA
}

\section{MANAGEMENT TAHFIDH AL-QUR'AN CLASS PROGRAM IN MIN 2 SLEMAN YOGYAKARTA}

\author{
Rendy Nugraha Frasandy \\ Dosen PGMI UIN Imam Bonjol Padang \\ Jl. Prof. Moh Yunus Lubuk Lintah, Kota Padang., Telp/Fax. 0752-20923 \\ Email : rendy.nugraha04@yahoo.co.id
}

\begin{abstract}
Abstrak
MIN 2 Sleman telah mengalami kemajuan pesat sejak bergantinya Kepala Madrasah. Sebelum itu keadaan MIN bukan menjadi "primadona" bagi para orang tua siswa dalam menitipkan anaknya. Hal ini ditandai dengan data penerimaan siswa baru yang tidak mencukupi kuota yang disediakan. Belum lagi tantangan MIN yang menjadi "pilihan kedua" setelah Sekolah Dasar. Dengan keresahan ini, Kepada Madrasah dituntut untuk dapat membuat inovasi pada MIN tersebut. Inovasi tersebut berupa program baru yang dirilis pada tahun 2017 dikenal dengan Kelas Tahfidh Al-Qur'an. Metode Penelitian yang digunakan adalah deskriptif kualitatif. Hasil penelitian menunjukan pada tahap perencanaan program, dimulai dengan menetapkan tujuan, menyiapkan materi, guru, alokasi waktu dan membuat perangkat pembelajaran di persiapkan dengan baik. Dalam pengorganisasian program telah memiliki struktur organisasi yang jelas. Dalam Pelaksanaan program dilakukan setiap hari senin hingga kamis dengan durasi 2x35 menit. Dalam pengawasan dilakukan pelaporan setiap Tri Wulan dan Semester untuk mengetahui target pencapaian siswa.
\end{abstract}

Kata Kunci: Manajemen, Tahfizh Al-Qur’an, MIN 2 Sleman Yogyakarta

\begin{abstract}
MIN 2 Sleman has progressed rapidly since the change of Head of Madrasah. Before that the MIN situation is not a "prima donna" for the parents of students in entrusting their children. This is indicated by new student admission data that is not sufficient for the quota provided. Not to mention the MIN challenge that became the "second choice" after elementary school. With this unrest, Madrasah is required to be able to make innovations on the MIN. The innovation of a new program released in 2017 is known as Tahfizh Class Al-Qur'an. The research method used is descriptive qualitative. The results of the study show in the planning phase of the program, starting with setting goals, preparing materials, teachers, allocation of time and make learning tools in the well prepared. In organizing the program has a clear organizational structure. In the implementation of the program is done every Monday to Thursday with a duration of $2 \times 35$ minutes. In the monitoring conducted reporting every Tri Wulan and Semester to know the target of student achievement.
\end{abstract}

Keywords: Management, Qur'an Tahfizh. MIN 2 Sleman Yogyakarta

\section{Pendahuluan}

Di Indonesia, Madrasah masih dipandang sebelah mata oleh sebagian masyarakat. Madrasah masih dianggap lembaga pendidikan kelas dua. Akibatnya, meskipun secara yuridis keberadaan Madrasah diakui sejajar dengan sekolah formal 
lainnya, Madrasah pada umumnya hanya diminati oleh siswa-siswi yang kemampuan intelegensi dan ekonomi yang sederhana. Sehingga upaya dan usaha untuk meningkatkan mutu Madrasah mengalami hambatan. Madrasah yang kurang memperhatikan potensi anak didik, akan dipandang negatif oleh masyarakat. Dan akan membuat para orang tua kecewa terhadap Madrasah tersebut. Sebab, pengetahuan yang dimiliki anak-anaknya masih terlihat biasa.

Idealnya Madrasah dan masyarakat memiliki hubungan yang sangat erat dalam mencapai tujuan Madrasah atau pendidikan secara efektif dan efisien. Madrasah hendaknya mengetahui apa kebutuhan masayarakat sehingga dapat memenuhinya. Dengan kata lain, antara Madrasah dan masyarakat harus dibina hubungan yang erat dan harmonis. Melalui hubungan yang erat dan harmonis tersebut, diharapkan terjalin tujuan hubungan Madrasah dengan masyarakat, yaitu terlaksananya proses pendidikan di Madrasah secara efektif, produktif, dan efisien, sehingga menghasilkan lulusan Madrasah yang produktif dan berkualitas. Seperti diungkapkan Mulyasa (2012:50-52), lulusan yang berkualitas, ini tampak dari penguasaan peserta didik terhadap ilmu pengetahuan, keterampilan dan sikap yang dapat dijadikan bekal untuk melanjutkan pendidikan pada jenjang berikutnya atau hidup di masyarakat sesuai dengan asas pendidikan seumur hidup.

Oleh karena itu Madrasah harus memiliki keunggulan yang berbeda di antara sekolah formal lainnya, dengan menambah atau merubah kebijakan dalam pengelolaan Madrasah tersebut. Karena hal ini merupakan tuntutan masyarakat terhadap kualitas pendidikan. Khususnya pada lembaga Madrasah Ibtidaiyah (MI). MI merupakan jenjang paling dasar pada pendidikan formal yang pengelolaannya dilakukan oleh Kementerian Agama. Kredibilitas Madrasah yang unggul tergantung dengan kepemimpinan. Jika pemimpin dapat mengelola Madrasah dengan baik, maka Madrasah tersebut dapat membawa lulusan yang lebih berkualitas dibanding dengan lulusan dalam sekolah formal lainnya.

Pemimpin yang piawai akan mampu menciptakan Madrasah yang kondusif dan persaingan sehat. Dampaknya adalah pada kualitas proses dan hasil pembelajaran. Kualitas pembelajaran akan mempengaruhi kualitas lulusan. Jika sekolah menginginkan kualitas lulusan yang baik, maka dipersyaratkan mutu pembelajaran harus baik.

Dalam hal ini peneliti tertarik untuk meneliti di MIN 2 Sleman Yogyakarta Tempel Kabupaten Sleman, Yogyakarta. Karena MIN ini merupakan salah satu Madrasah yang dikenal sebagai Madrasah pertama yang membuat program baru yaitu Tahfidh Al-Qur'an dengan kepala Madrasah yang bernama Ali Shofa. Alasan Ali Shofa membuat program Hafidz Al-Qur'an ini adalah untuk menjadikan lulusan yang berkualitas dan ingin menjadikan siswa-siswinya menjadi anak yang sholeh dan solehah, menjadikan Madrasah yang Unggul dan menjadi pilihan utama orang tua siswa.

Pada awalnya program tahfidh Al-Qur'an dilaksanakan hanya pada awal pembelajaran dengan durasi 10-15 menit, dan baru dicobakan kepada kelas 4 dan 5 . Seiring perkembangannya terlihat sambutan dan antusias masyarakat dengan baik dengan dicetuskannya program Tahfidh Al-Qur'an ini pada tahun 2014 membuat MIN 2 Sleman mulai "dilirik" oleh masyarakat, khususnya bagi orang tua dalam menitipkan anaknya ke Madrasah tersebut. Hal ini ditandai dengan data penerimaan siswa baru pada tahun ajaran 2015/2016 mengalami perlonjakan yang signifikan. Kuota siswa yang disediakan Madrasah tercukupi bahkan berlebih. 
Pada tahun 2017 Ali Shofa selaku Kepala Madrasah kembali mencetuskan inovasi baru dengan membuat program tahfidh Al-Qur'an yang hanya dilaksanakan pada awal pembelajaran dengan durasi 10-15 sebelum pembelajaran dimulai dan hanya pada kelas 4 dan 5, menjadi program Kelas Tahfidh Al-Qur'an yang dimulai dari kelas 1 sampai kelas 4. Seperti harapan yang diyakini bersama warga Madrasah program kelas Tahfidh Al-Qur'an "ramai peminat" dan menjadi alasan utama para orang tua dalam menitipkan anaknya di Madrasah tersebut. Sehingga peneliti tertarik, untuk dapat melihat lebih jauh terkait manajemen program kelas tahfidh Al-Qur'an di MIN 2 Sleman Yogyakarta?

Tujuan dari penelitian ini adalah untuk mengetahui suatu proses manajemen yang direncanakan secara cermat oleh pendidik dan pengelola kependidikan MIN 2 Sleman Yogyakarta dalam pembelajaran tahfidh Al-Qur'an yang meliputi perencanaan, pelaksanaan, pengorganisasian, dan pengawasan, sesuai dengan teori fungsi dasar manajemen dari Terry dan Franklin (2003:11), yang meliputi Planning, organizing, actuating and controlling atau dikenal dengan istilah POAC.

\subsection{Pengertian}

Menurut Terry dan Franklin (2003:4), manajemen adalah the process of designing and maintaning an environment in wich individuals, working together in groups, efficienctly accomplish selected aims (suatu proses yang terdiri dari perencanaan, pengaturan, penggerakan dan pengendalian yang dilakukan untuk menentukan dan memenuhi sasaran dan hasil yang diwujudkan dengan menggunakan manusia dan sumber daya lainnya).

Lebih lanjut George R. Terry (2003:6-8) merumuskan fungsi manajemen menjadi empat fungsi pokok yaitu: a) Planning (Perencanaan); b) Organizing (pengorganisasian); c) Actuatting (Pelaksanaan); d) Controlling (Pengawasan). Keempat fungsi pokok inilah yang peneliti gunakan sebagai analisa dalam menilai manajemen atau pengelolaan kelas tahfidh Al-Qur'an di MIN 2 Sleman Yogyakarta. Manajemen sebuah program dapat dinilai sudah berjalan baik apabila telah memasukan empat fungsi pokok ini.

Menurut Mahmud Yunus (1990:105), tahfidh al-Qur'an terdiri dari dua suku kata yaitu tahfidh dan al-Qur'an, yang mana keduanya mempunyai arti yang berbeda, yaitu tahfidz yang berarti menghafal. Menghafal dari kata dasar hafal yang dari bahasa arab hafidza-yahfidzu-hifdzan, yaitu lawan dari lupa yaitu selalu ingat dan sedikit lupa. Sedangkan menurut Aziz Abdul Rauf (2004:49), definisi menghafal yaitu proses mengulang sesuatu baik dengan membaca atau mendengar, karena pekerjaan apapun kalau sering diulang pasti menjadi hafal.

Dalam terbitan lain Kamus Mahmud Yunus (2009:107) tahfidh juga berarti menjaga berangkat dari akar kata hafazho. Tahfidh termasuk kepada mashdar yang berarti menjaga dengan sangat. Adapun makna yang dimaksud disini adalah menghafal Al-Qur'an. Pembelajaran Tahfidh Al-Qur'an yang dimaksud dalam penelitian ini adalah proses belajar mengajar Al-Qur'an dengan cara menghafal dalam rangka usaha meresapkan ayat-ayat Al-Qur'an ke dalam pikiran atau memori ingatan. Kegiatan ini dilaksanakan di Madrasah Ibtidaiyah Negeri 2 Sleman Yogyakarta. 


\subsection{Deskripsi Lokasi Penelitian}

Madrasah Ibtidaiyah Negeri 2 Sleman adalah Sekolah Dasar yang berciri khas Islam dibawah nauangan Kementerian Agama DIY. Madrasah ini didirikan tanggal 31 Mei 1980, dan saat ini telah berusia 37 tahun, terletak di dusun Gandok, Sinduharjo, Ngaglik, Sleman, tepatnya berada di jalan Kaliurang km 9,3, telepon (0274) 885420. Saat ini kepemimpinan Madrasah tersebut di pegang oleh Bapak Ali Shofa sebagai Kepala Madrasah.

Madrasah Ibtidaiyah Negeri 2 Sleman memiliki visi yaitu prestasi tinggi, berakhlak qurani, percaya diri, sehat berwawasan lingkungan dan inovatif. Misinya adalah memberdayakan tenaga pendidik dan kependidikan yang memenuhi Standar Nasional Pendidikan yang ditetapkan, diantaranya a) menanamkan kedisiplinan melalui budaya bersih, budaya tertib, dan budaya kerja, b) menumbuhkan penghayatan terhadap budaya adiluhung dan seni daerah sehingga menjadi salah satu sumber kearifan berperilaku dan bermasyarakat; c) menumbuhkan inovasi dalam kehidupan sehari hari yang dapat menunjang pengembangan profesionalisme; d) memberdayakan seluruh komponen sekolah dan mengoptimalkan sumber daya sekolah dalam mengembangkan potensi siswa secara optimal.

Sedangkan tujuan Madrasah ini tidak terlepas dari tujuan umum pendidikan, yaitu meningkatkan kecerdasan, pengetahuan, kepribadian, akhlak mulia, serta keterampilan untuk hidup mandiri dan mengikuti pendidikan lebih lanjut. Tujuan umum tersebut diharapkan akan tercapai secara meyeluruh dan berkesinambungan. Namun, secara bertahap ditetapkan tujuan khusus yang akan dicapai pada tahun pelajaran 2016/2017 sebagai berikut: a) Menyediakan sarana prasarana pendidikan yang memadai; b) Melaksanakan proses belajar mengajar secara efektif dan efisien, berdasarkan semangat keunggulan lokal dan global; c) Meningkatkan kinerja masingmasing komponen sekolah (Kepala sekolah, guru, karyawan, siswa, dan komite sekolah) untuk bersama-sama melaksanakan kegiatan yang inovatif sesuai dengan tugas pokok dan fungsi masing-masing; d) Meningkatkan program ekstrakurikuler agar lebih efektif dan efisien sesuai dengan bakat dan minat siswa sebagai salah satu sarana pengembangan diri siswa; e) Mewujudkan peningkatkan kualitas dan jumlah tamatan yang melanjutkan ke SMP/MTs/Pondok Pesantren; f) Menyusun dan melaksanakan tata tertib dan segala ketentuan yang mengatur operasional warga sekolah;) Meningkatkan kualitas semua sumber daya manusia baik pendidik, tenaga kependidikan dan siswa yang dapat berkompetisi baik lokal maupun global.

\section{Metode Penelitian}

\subsection{Jenis dan Pendekatan}

Penelitian ini merupakan penelitian lapangan dengan menggunakan metode deskriptif kualitatif. Menurut Lexy J Moleong (2013:5) Penelitian kualitatif adalah penelitian yang menggunakan latar belakang ilmiah dengan maksud menafsirkan fenomena yang terjadi dan dilakukan dengan melibatkkan berbagai metode yang ada. Penelitian kualitatif merupakan penelitian yang memanfaatkan wawancara terbuka untuk menelaah dan memahami sikap, pandangan, perasaan dan prilaku individu atau kelompok orang. Menurut Bogdan dan Taylor (1992:22), metodologi kualitatif adalah prosedur penelitian yang menghasilkan data deskriptif kualitatif berupa kata-kata tertulis atau lisan dari orang-orang dan perilaku yang diamati. Menurut keduanya, pendekatan ini diarahkan pada latar dan individu secara menyeluruh (holistik). 
Pendekatan yang digunakan dalam penelitian ini adalah pendekatan fenomenologi. Fenomenologi mempercayai bahwa kebenaran sesuatu itu dapat diperoleh dengan cara menangkap fenomena atau gejala yang memancar dari objek yang diteliti. Fenomenologi dalam penelitian ini adalah pengalaman manusia melalui deskripsi dari orang yang menjadi partisipan penelitian secara tidak langsung, yaitu peneliti. Peneliti ini dapat memahami pengalaman hidup partisipan. Menurut Afifudin (2009:88), pendekatan fenomenologis meneliti keadaan gejala sebagaimana apa adanya, membiarkan objek sebagai subjek, dan peneliti ini tidak terlalu menafsirkan apa yang ada karena cara tersebut dipandang mempertinggi subjektivitas penelitian.

\subsection{Sumber Data}

Menurut Lofland dalam Moleong (2013:157), sumber data utama dalam penelitian kualitatif ialah kata-kata, dan tindakan, selebihnya adalah data tambahan, seperti dokumen, wawancara, dan foto. Berkaitan dengan hal tersebut, pada bagian ini jenis datanya dibagi ke dalam kata-kata dan tindakan, sumber data tertulis, foto, dan statistik. Sedangkan menurut Sugiono (2015:297) dalam penelitian kualitatif tidak menggunakan istilah populasi, tetapi oleh Spradley dinamakan "social situation" atau situasi sosial yang terdiri dari tiga elemen yaitu tempat, pelaku, dan aktifitas. Situasi sosial tersebut dapat dinyatakan sebagai objek penelitian yang ingin pahami secara lebih dalam. Dalam penelitian ini yang dimaksud dengan objek penelitian adalah kelas tahfidh Al-Qur'an di MIN 2 Sleman Yogyakarta, aktivitasnya adalah pembelajaran Tahfidh, dan pelakunya adalah guru dan peserta didik. Sugiono juga berpendapat (2015:298) dalam penelitian kualitatif tidak menggunakan populasi namun sampel. Sampel dalam penelitian kualitatif disebut sebagai narasumber, informan atau partisipan yang merupakan sumber data. Penentuan sumber data secara purposive, yaitu dipilih dengan pertimbangan dan tujuan dan tertentu. Sumber data dalam penelitian ini adalah kepala Madrasah, kepala penjamin mutu, guru tahfidh dan siswa.

\section{3. Teknik dan Instrumen Pengumpulan Data}

Data yang diperlukan dalam penelitian ini menggunakan teknik dan instrumen pengumpulan data yang relevan dengan penelitian. Data tersebut diperoleh melalui: 1) Wawancara; 2) Observasi; dan 3) dokumentasi. Menurut Moloeng (2013:186), wawancara adalah percakapan dengan maksud tertentu. Percakapan itu dilakukan oleh dua pihak, yaitu pewawancara (interviewer) yang mengajukan pertanyaan dan terwawancara (interviewee) yang memberikan jawaban atas pertanyaan itu. Wawancara ini dimaksudkan untuk mengkontruksi mengenai orang, kejadian, organisasi, perasaan, motivasi, tuntutan, kepedulian, dan lain-lain. Menurut Sugiono (2015:138-140) metode wawancara yang digunakan melalui dua cara, yaitu wawancara terstruktur dan tak terstruktur. Wawancara terstruktur digunakan sebagai teknik pengumpulan data, bila peneliti atau pengumpul data telah mengetahui dengan pasti tentang informasi apa yang akan diperoleh. Oleh karena itu dalam melakukan wawancara, pengumpul data telah menyiapkan instrumen penelitian berupa pertanyaan-pertanyaan tertulis yang alternatif jawabannya pun telah disiapkan. Wawancara tidak terstruktur adalah wawancara yang bebas dimana peneliti tidak menggunakan pedoman wawancara yang telah tersusun secara sistematis dan lengkap untuk pengumpulan datanya. Pedoman wawancara yang digunakan hanya berupa garis-garis besar permasalahan yang akan ditanyakan. Dalam penelitian ini teknik wawancara yang digunakan untuk mengetahui manajemen kelas tahfidh Al-Qur'an melalui wawancara langsung dengan Kepala Madrasah. Wawancara 
ini digunakan pula untuk uji keabasahan data melalui kepala penjamin mutu, guru tahfidh, dan siswa.

Menurut Uhar Suharsapurta (2012:209), observasi berarti memperhatikan dengan penuh perhatian seseorang atau sesuatu, memperhatikan dengan penuh perhatian berarti mengamati tentang apa yang terjadi. Menurut Denzim dalam bukunya Dedy Mulyana (2002:163) dalam observasi, observer/pengamat dapat berpartisipasi sebagai pengamat (participant as observer) dengan membiarkan kehadirannya sebagai peneliti dan mencoba membentuk serangkaian hubungan dengan subyek sehingga mereka berfungsi sebagai responden dan informan. Jadi observasi adalah seorang peneliti mengamati dan memperhatikan secara langsung maupun tidak langsung tentang apa yang terjadi terhadap seseorang yang berfungsi sebagai responden dan informan dalam sebuah penelitian. Untuk memperoleh data, salah satu metode yang digunakan oleh peneliti ini adalah observasi. Pada penelitian ini peneliti melakukan observasi tidak terstruktur, yaitu peneliti dalam mencari data tidak dipersiapkan secara sistematis tentang apa yang diobservasikan. Dalam melakukan pengamatan peneliti ini tidak menggunakan instrumen yang telah baku, tetapi hanya berupa rambu-rambu pengamatan. Metode ini digunakan untuk mengetahui, gambaran manajemen MIN 2 meliput planning, organizing, actuating dan controlling (POAC) pada kelas tahfifd AlQur'an.

Selajutnya dokumentasi merupakan rekaman kejadian masa lalu yang ditulis atau dicetak, dapat berupa catatan anekdot, surat, buku harian, dan dokumen-dokumen lain. Metode ini digunakan oleh peneliti untuk memperoleh data berupa: sejarah berdirinya, struktur organisasi, kegiatan pembelajaran tahfidh di MIN 2 Sleman Yogyakarta yang telah dibukukan atau didokumentasikan dan dokumen lain yang relevan.

\subsection{Analisis Data dan Pengecekan Keabsahan Data \\ 2.4.1 Analisis Data}

Data yang telah terkumpul dianalisis secara induktif dan berlangsung selama pengumpulan data di lapangan, dan dilakukan secara terus-menerus. Cara berfikir induktif dalam penelitian adalah penelitian dapat dilaksanakan tanpa mendasarkan teori terlebih dahulu, akan tetapi tidak membatasi peneliti jika sudah mempunyai teori yang akan digunakan terlebih dahulu. Menurut Miles dan Heberman dalam Sugiono (2015:91) analisis data ada tiga langkah yaitu: 1) Reduksi Data; 2) Display data; 3) Verifikasi Data.

Reduksi data yaitu semua data di lapangan akan dianalisis sekaligus, dirangkum, selanjutnya dipilih hal-hal yang pokok dan difokuskan pada hal-hal yang penting, dicari tema dan polanya sehingga tersusun secara sistematis. Oleh karena itu, reduksi data berlangsung secara terus menerus selama penelitian berlangsung. Dalam mereduksi data semua data di lapangan dikumpulkan, ditulis, dianalisis, dirangkum, dipili hal-hal yang penting, dicari tema dan polanya disususn secara sistematis. Dalam proses penelitian ini peneliti menelaah seluruh data yang sudah dihimpun dari lapangan sekaligus memilih dan merangkum data yang berkaitan dengan manajemen kelas tahfidh Al-Qur'an di MIN 2 Slemen Yogyakarta.

Display data yaitu teknik yang dilakukan oleh peneliti agar data yang diperoleh yang berjumlah banyak, dapat dikuasai setelah itu data disajikan yang memungkinkan adanya penarikan kesimpulan dan pengambilan tindakan. Seperangkat hasil reduksi data tersebut diorganisasikan ke dalam penyajian data (display data). Pada tahap ini 
penyajian data dilakukan dengan membuat rangkuman secara induktif berdasarkan data yang dimiliki dan disusun secara sistematis dalam bentuk narasi mengenai manajemen kelas tahfidh Al-Qur'an.

Verifikasi data yaitu teknik analisis data yang dilakukan dalam rangka penarikan simpulan dan mencoba untuk menyimpulkan data dari berbagai sumber, kemudian peneliti mengambil simpulan yang bersifat sementara sambil mencari data pendukung. Pada langkah ini peneliti menyusun data secara sistematis dari berbagai data yang diperoleh di lapangan, kemudian menyajikan data, dan menarik kesimpulan dari datadata yang diperoleh yang sesuai dengan fokus penelitian. Selain itu peneliti juga melakukan pengkajian tentang simpulan yang telah diambil dari data pembanding teori. Pengujian ini dimaksudkan untuk melihat kebenaran hasil analisis dari simpulan yang dapat dipercaya.

Ditambahkan Margono (2014: 38) Pada tahap analisis data dikerjakan dan dimanfaatkan sedemikian rupa sampai berhasil dan menjawab pertanyaan atau persoalan yang diajukan dalam penelitian. Analisis data dilakukan secara induktif, penelitian dimulai dari fakta empiris, kemudian ke lapangan mempelajari, menganalisis, menafsirkan dan menarik kesimpulan dari fenomena yang ada di lapangan.

\subsubsection{Pengecekan Keabsahan Data}

Menurut Sugiono (2015: 368), untuk menguji keabsahan atau kredibilitas data ada beberapa usaha yang bisa dilakukan peneliti dalam penelitian kualitatif antara lain dengan perpanjangan pengamatan, peningkatan ketekunan dalam penelitian, triangulasi, diskusi dengan teman sejawat, analisi kasus negatif, dan member cek. Berikut beberapa cara untuk uji keabsahan data dalam penelitian ini :

a. Memperpanjang kehadiran

Pada penelitian ini peneliti menjadi insrtrumen penelitian. Oleh karena itu kehadiran peneliti dalam mengumpulkan berbagai data dan informasi tidak cukup dalam waktu yang singkat, maka diperlukan perpanjang waktu kehadiran untuk menunjang kepercayaan data yang dikumpulkan. Kegiatan ini dilakukan untuk menimbang dan mempertajam data yang dikumpulkan di lapangan sehingga dapat menjadi akurat dan lengkap data yang diperoleh peneliti di lapangan. Penelitian ini peneliti mulai bulan mei 2017 sampai september 2017 kemudian peneliti memperpanjang sampai menemukan data yang lengkap dan menunjang dalam penelitian dan data serta informasi yang akurat.

b. Ketekunan dalam penelitian

Untuk menguji keabsahan dan kredibilitas data, peneliti melakukan ketekunan penelitian dalam hal ini ketekunan pengamatan dan melihat serta mencermati berbagai aktivitas guru dan peserta didik baik di dalam kelas maupun di luar kelas, serta memperhatikan berbagai karakteristik peserta didik dalam kegiatan pembelajaran.

c. Triangulasi

Triangulasi diartikan sebagai teknik pengumpulan data yang bersifat menggabungkan dari berbagai teknik pengumpulan data dan sumber data yang telah ada. Peneliti melakukan pengumpulan data dengan triangulasi, maka sebenarnya peneliti mengumpulkan data sekaligus mengecek kredibilitas data yaitu mengecek kredibilitas data dengan berbagai teknik pengumpulan data dan berbagai sumber data. Triangulasi teknik berarti peneliti menggunakan teknik pengumpulan data yang berbeda-beda untuk mendapatkan data dari sumber yang sama. Peneliti menggunakan 
observasi partisipatif, wawancara mendalam dan dokumentasi untuk sumber data yang sama secara serempak.

Nilai dari teknik pengumpulan data dengan triangulasi adalah untuk mengetahui data yang diperoleh convergent (meluas) tidak konsisten atau kontradiktif. Oleh karena itu dengan menggunakan teknik triangulasi dalam pengumpulan data maka data yang diperoleh akan lebih konsisten, tuntas dan pasti. Dengan triangulasi akan lebih meningkatkan kekuatan data, bila dibandingkan dengan satu pendekatan.

Pada saat kegiatan penelitian, peneliti menggunakan triangulasi metode ganda, dengan cara membandingkan data hasil pengamatan dengan data hasil wawancara serta data dokumentasi sekolah. Dalam hal ini peneliti mengadakan wawancara dengan kepala MIN 2 Sleman Yogyakarta. Kemudian peneliti mengadakan cross chek dengan kepala penjamin mutu, guru tahfidh dan siswa mengenai informasi yang didapat dalam penelitian ini.

\section{Kegiatan Tahfidh Al-Qur'an di MIN 2 Sleman Yogyakarta}

Dari hasil penelitian yang dilakukan di MIN 2 Sleman Yogyakarta, dapat dideskripsikan sebagai berikut:

\subsection{Perencanaan (Planning)}

Menurut Abdul Majid (2011:17), perencanaan merupakan proses kegiatan yang menyiapkan secara sistematis kegiatan yang akan dilakukan untuk mencapai tujuan yang diinginkan. Perencanaan yang dilakukan guru akan menentukan keberhasilan pembelajaran yang dipimpinnya, hal ini didasarkan dalam membuat guru lebih mudah alam hal penyampaian materi pembelajaran pengorganisasian peserta didik di kelas maupun pelaksanaan evaluasi pembelajaran baik proses maupun hasil belajar.

Mengenai perencanaan program kelas tahfidh Al-Qur'an dapat dijelaskan melalui tahapan-tahapan, yaitu:

\subsubsection{Tujuan program kelas tahfidh Al-Qur'an Al-Qur'an}

Menurut Kepala MIN 2 Sleman Yogyakarta, Ali Shofa, tujuan yang ingin dicapai dalam program kelas tahfidh Al-Qur'an Al-Qur'an yaitu:

a. Membentuk siswa siswi yang memiliki berbagai pengetahuan agama, memiliki dasar-dasar agama yang kuat berupa Al-Qur'an dan memiliki berbagai ilmu penunjang yang lainnya.

b. Untuk mendorong siswa siswi untuk suka menghafal Al-Qur'an dan mengamalkannya ke dalam kehidupan sehari-hari.

c. Siswa yang menyelesaikan belajarnya di MIN 2 Sleman Yogyakarta dapat menghafal Al-Qur'an minimal 3 juz. berikut:

Dalam penyusunan tujuan tersebut, perlu mempertimbangkan hal-hal sebagai

a. Kemampuan dan nilai-nilai yang ingin dikembangkan pada diri siswa

b. Bagaimana cara mencapai tujuan itu secara bertahap atau sekaligus

c. Apakah perlu menekankan aspek-aspek ternteu atau tidak

d. Seberapa jauh tujuan itu dapat memenuhi kebutuhan perkembangan siswa

e. Apakah waktu yang tersedia cukup untuk mencapai tujuan tersebut.

3.1.2 Penentuan Materi Tahfidz Al-Qur'an

Sebelum merencanakan program kelas tahfidh Al-Qur'an Al-Qur'an, terlebih dahulu diadakan rapat dengan unsur terkait.

Sesuai hasil wawancara dengan Kepala Penjamin Mutu Isa Ashori bersama wali siswa Isti, materi hafalan pada MIN 2 Sleman Yogyakarta, yaitu: 
a. Kelas I dan II meliputi pengenalan huruf, perbaikan bacaan dan hafalan Al-Qur'an. Skala prioritasnya adalah pada perbaikan bacaan Al-Qur'an.

b. Kelas III dan IV meliputi perbaikan bacaan, hafalan Al-Qur'an dengan skala prioritas adalah pada peningkatan kualitas bacaan dan penguatan hafalan.

Target yang diinginkan pada MIN 2 Sleman Yogyakarta adalah siswa siswi khususnya kelas 1,2,3 dan 4 dapat membaca dan menghafal Al-Qur'an dengan sebaikbaiknya sesuai dengan kaidah tajwid dan makhrajnya.

3.1.3 Penentuan Alokasi Waktu dan Jam Pelajaran

Alokasi waktu disini adalah perkiraan berapa lama peserta didik mempelajari materi yang telah ditentukan. Alokasi perlu diperhatikan untuk memperkirakan jumlah jam tatap muka yang diperlukan.

3.1.4 Membuat perangkat perencanaan

Perencanaan merupakan proses kegiatan yang menyiapkan secara sistematis kegiatan yang akan dilakukan untuk mencapai tujuan yang diinginkan. Perencanaan yang dilakukan guru akan menentukan keberhasilan pembelajaran yang dipimpinnya. Hal ini disasarkan dengan membuat sebuah rencana yang baik atau lebih terperinci akan membuat guru lebih mudah dalam penyampaian materi pembelajaran.

\subsection{Pengorganisasian (Organizing)}

Kegiatan program kelas tahfidh Al-Qur'an di MIN 2 Sleman Yogyakarta tidak dapat berjalan dengan baik dan optimal apabila tidak memiliki pengorganisasian yang baik. Sehingga dalam mewujudkan kelas tahfidh yang baik dan optimal tersebut di bentuklah stuktur organisasi pengelolaan kelas tahfidh MIN 2 Sleman Yogyakarta seperti berikut ini:

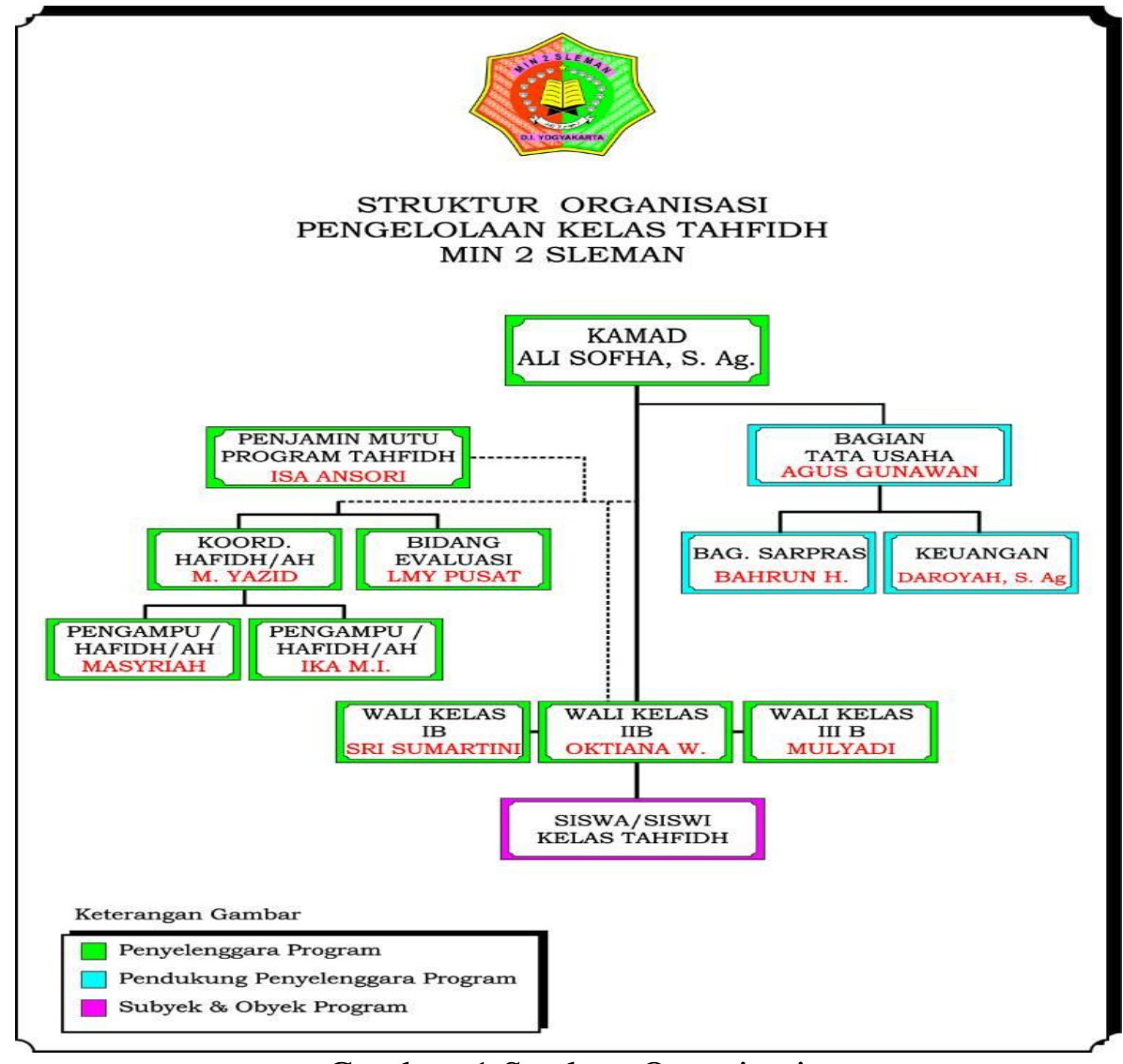

Gambar. 1 Struktur Organisasi 
Pada gambar diatas telah cukup jelas diungkapkan bahwa program kelas tahfidh Al-Qur'an diorganisasikan langsung dibawah garis komando Bapak Ali Shofa selaku Kepala Madrasah, selanjutnya penyelenggaraan kelas tahfidh Al-Qur'an dikelola oleh Bapak Isa Anshori selaku Kepala Penjamin Mutu Program Tahfidh Al-Qur'an dibantu dengan koordinator hafidz/hafidzah (sebutan untuk guru tahfidh Al-Qur'an) dan Koordinator bidang evaluasi serta yang tidak kalah penting adalah para guru tahfidh AlQur'an dan wali kelas I, II III dan IV tersebut. Penyelenggaraan program kelas tahfidh Al-Qur'an tidak akan berjalan baik dan optimal jika tidak didukung oleh pihak-pihak lain, seperti unsur tata usaha yang meliputi bagian sarana prasarana dan pembiayaan. terakhir sebagai subjek program kelas tahfidh Al-Qur'an ialah para siswa baik kelas I, II, III dan IV.

\subsection{Pelaksanaan (Actuating)}

Program kelas tahfidh Al-Qur'an atau disebut juga dengan pembelajaran Tahfidh di MIN 2 Sleman Yogyakarta dilaksanakan setiap hari senin sampai kamis. Namun untuk waktu pelaksanaan berbeda-beda disesuaikan pada tim pengajarnya, dengan mempertimbangkan keterbatasan tim pengajar pada program tahfidh tersebut. Pada kelas I B dari pukul 07.00 WIB sampai pukul 08.10 WIB, Pada kelas IIB pada pukul 10.00 WIB sampai pukul 11.10 WIB. Pada kelas IIIB pada 11.15 WIB sampai pukul 12.25 WIB. Pada kelas IVB pada 12.30 WIB sampai pukul 14.10 WIB. Untuk memudahkan pembacaan mengenai program kelas tahfidh Al-Qur'an di MIN 2 Sleman Yogyakarta dapat dilihat pada tabel pencapaian target program kelas tahfidh Al-Qur'an berikut ini:

TARGET PENCAPAIAN KELAS TAHFIDH MIN 2 SLEMAN

Kelas I

\begin{tabular}{|c|c|c|c|c|}
\hline NO & $\begin{array}{l}\text { ALOKASI } \\
\text { WAKTU }\end{array}$ & URAIAN & $\begin{array}{c}\text { CAPAIAN } \\
\text { YANG } \\
\text { DIHARAPKAN }\end{array}$ & REFERENSI \\
\hline \multicolumn{5}{|c|}{ Kelas I. Semester I } \\
\hline \multirow[t]{2}{*}{$\mathbf{1}$} & Tri wulan I & $\begin{array}{l}\text { Pengenalan Huruf dan } \\
\text { perbaikan bacaan }\end{array}$ & Jilid I & Kitab Yambuá \\
\hline & & - Hafalan Al Quran & $\begin{array}{l}\text { Adh-Dhuha- } \\
\text { Al Ghosiyah }\end{array}$ & Quran Pojok \\
\hline \multirow[t]{2}{*}{2} & Tri wulan II & $\begin{array}{l}\text { Pengenalan Huruf dan } \\
\text { perbaikan bacaan }\end{array}$ & Jilid II & Kitab Yambuá \\
\hline & & - Hafalan Al Quran & $\begin{array}{l}\text { Adh-Dhuha- } \\
\text { Al Ghosiyah }\end{array}$ & Quran Pojok \\
\hline \multicolumn{5}{|c|}{ Kelas I. Semester II } \\
\hline \multirow[t]{2}{*}{3} & Tri wulan I & $\begin{array}{l}\text { Pengenalan Huruf dan } \\
\text { perbaikan bacaan }\end{array}$ & Jilid III & Kitab Yambuā \\
\hline & & C Hafalan Al Quran & $\begin{array}{l}\text { Adh-Dhuha- } \\
\text { Al Ghosiyah }\end{array}$ & Quran Pojok \\
\hline \multirow[t]{2}{*}{4} & Tri wulan II & $\begin{array}{l}\text { Pengenalan Huruf dan } \\
\text { perbaikan bacaan }\end{array}$ & Jilid IV & Kitab Yambuá \\
\hline & & > Hafalan Al Quran & $\begin{array}{l}\text { Adh-Dhuha- } \\
\text { Al Ghosiyah }\end{array}$ & Quran Pojok \\
\hline & 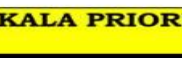 & $\begin{array}{l}\text { SEMBELAJARAN TAHF } \\
\text { PERBAIKAN BACAAN }\end{array}$ & $\begin{array}{l}\text { I DI KELAS I } \\
\text { QURAN }\end{array}$ & ILAH I \\
\hline
\end{tabular}

Kelas II

\begin{tabular}{|c|c|c|c|c|}
\hline No & $\begin{array}{l}\text { ALOKASI } \\
\text { WAKTU }\end{array}$ & URAIAN & $\begin{array}{c}\text { CAPAIAN } \\
\text { YANG } \\
\text { DIHARAPKAN }\end{array}$ & REFERENSI \\
\hline \multirow[t]{2}{*}{$\mathbf{1}$} & Semester I & $\begin{array}{ll}\begin{array}{l}\text { Perbaikan } \\
\text { Quran } \\
\text { huruf) }\end{array} & \begin{array}{l}\text { bacaan Al } \\
\text { (Makharijul }\end{array} \\
\end{array}$ & Jilid V & Kitab Yambuá \\
\hline & & > Hafalan Al Quran & $\begin{array}{c}\text { Al Ála-An } \\
\text { Naba' } \\
\text { Juz (30 } \\
\text { khatam) }\end{array}$ & Quran Pojok \\
\hline \multirow[t]{2}{*}{2} & Semester II & $\begin{array}{ll}\text { Perbaikan } & \text { bacaan Al } \\
\text { Quran } & \text { (Makharijul } \\
\text { huruf) } & \\
\end{array}$ & Jilid VI & Kitab Yambuá \\
\hline & & - Hafalan Al Quran & $\begin{array}{l}\text { Juz } 1 \\
\text { Al Quran }\end{array}$ & Quran Pojok \\
\hline
\end{tabular}


Kelas III

\begin{tabular}{|c|c|c|c|c|c|}
\hline NO & $\begin{array}{c}\text { ALOKASI } \\
\text { WAKTU }\end{array}$ & \multicolumn{2}{|c|}{ URAIAN } & $\begin{array}{c}\text { CAPAIAN } \\
\text { YANG } \\
\text { DIHARAPKAN }\end{array}$ & REFERENSI \\
\hline 1 & $\begin{array}{l}\text { Semester } \\
\text { I \& II }\end{array}$ & $\begin{array}{l}\text { Perbaikan } \\
\text { Quran } \\
\text { huruf) }\end{array}$ & $\begin{array}{c}\text { bacaan Al } \\
\text { (Makharijul }\end{array}$ & $\begin{array}{l}\text { Penguatan } \\
\text { jilid I -VI }\end{array}$ & Kitab Yambuá \\
\hline & & $>$ Hafalan $\mathrm{Al} \mathrm{C}$ & uran & Juz 2-4 & Quran Pojok \\
\hline
\end{tabular}

Kelas IV

\begin{tabular}{|c|c|c|c|c|c|}
\hline No & $\begin{array}{c}\text { ALOKASI } \\
\text { WAKTU }\end{array}$ & \multicolumn{2}{|c|}{ URAIAN } & $\begin{array}{c}\text { CAPAIAN } \\
\text { YANG } \\
\text { DIHARAPKAN }\end{array}$ & REFERENSI \\
\hline 1 & $\begin{array}{l}\text { Semester } \\
\text { I \& II }\end{array}$ & $\begin{array}{l}\text { Perbaikan } \\
\text { Quran } \\
\text { huruf) }\end{array}$ & $\begin{array}{c}\text { bacaan Al } \\
\text { (Makharijul }\end{array}$ & jilid VII & Kitab Yambuá \\
\hline & & $>$ Hafalan $\mathrm{Al} \mathrm{Q}$ & uran & 5 & Quran Pojok \\
\hline
\end{tabular}

Gambar 2: Target pencapaian kelas I, II, III, dan IV tahfidh MIN 2 Sleman

Program Pelaksanaan program kelas tahfidh Al-Qur'an di MIN 2 Sleman Yogyakarta dapat diukur dengan menentukan target pencapaian tiap kelasnya. Target pencapaian tiap tingkatan tentu berbeda-beda. Pada kelas I target pencapaian program dialokasikan waktu 2 (dua) kali tiap semesternya atau 4 (empat) kali per tahunnya, dengan uraian kegiatan: 1) Pada tri wulan I pengenalan huruf dan perbaikan bacaan jilid I dan hafalan Al-Qur-an surat Adh-Dhuha dan Al-Ghosiyah. 2) Pada tri wulan II pengenalan huruf dan perbaikan bacaan jilid II dan hafalan Al-Qur-an surat Adh-Dhuha dan Al-Ghosiyah. 3) Pada tri wulan III pengenalan huruf dan perbaikan bacaan jilid III dan hafalan Al-Qur-an surat Adh-Dhuha dan Al-Ghosiyah. 4) Pada tri wulan IV pengenalan huruf dan perbaikan bacaan jilid IVdan hafalan Al-Qur-an surat Adh-Dhuha dan Al-Ghosiyah.

Selanjutnya untuk kelas II target pencapaian program dialokasikan waktu 1 (dua) kali tiap semesternya atau 2 (empat) kali per tahunnya, dengan uraian kegiatan: 1) Pada semester I perbaikan bacaan Al-Qur'an berkaitan dengan makharijul huruf Jilid V dan hafalan Al-Qur'an surat Al-Ala dan An-Naba. 2. Pada semester II perbaikan bacaan Al-Qur'an berkaitan dengan makharijul huruf Jilid VI dan hafalan Al-Qur'an Juz 1.

Selanjutnya untuk kelas III target pencapaian program dialokasikan waktu 1 (dua) kali tiap semesternya atau 2 (empat) kali per tahunnya, dengan uraian kegiatan: Pada semester I dan II perbaikan bacaan Al-Qur'an berkaitan dengan makharijul huruf Jilid I-VI dan hafalan Al-Qur'an dari Juz 2-4. Terakhir untuk kelas IV target pencapaian program dialokasikan waktu 1 (dua) kali tiap semesternya atau 2 (empat) kali per tahunnya, dengan uraian kegiatan: Pada semester I dan II perbaikan bacaan Al-Qur'an berkaitan dengan makharijul huruf Jilid VII dan hafalan Al-Qur'an dari Juz 5. Skala 
prioritas pembelajaran tahfidh Al-Qur'an di kelas IV adalah peningkatan kualitas bacaan dan penguatan hafalan siswa.

\subsection{Pengawasan (Controlling)}

Pengawasan mempunyai peranan atau yang penting dalam manajemen, dengan mempertimbangkan mempunyai fungsi untuk menguji apakah pelaksaan program kelas tahfidh Al-Qur'an, tertib, terarah dan sesuai dengan tujuan yang diinginkan atau tidak. Walaupun kegiatan planning, organizing dan actuating baik, tetapi tidak dilakukan kegiatan controlling dengan baik, tertib dan berkelanjutan maka tujuan yang telah ditetapkan tidak akan tercapai. Untuk itu pada program kelas tahfidh Al-Qur'an di MIN 2 Sleman Yogyakarta agar dapat berjalan sesuai dengan tujuan yang telah ditetapkan maka dibuatkahlah buku Prestasi Tahfidh Al-Qur'an yang meliputi catatan perkembangan tahfidh dan catatan perkembangan bacaan, seperti pada contoh berikut ini:

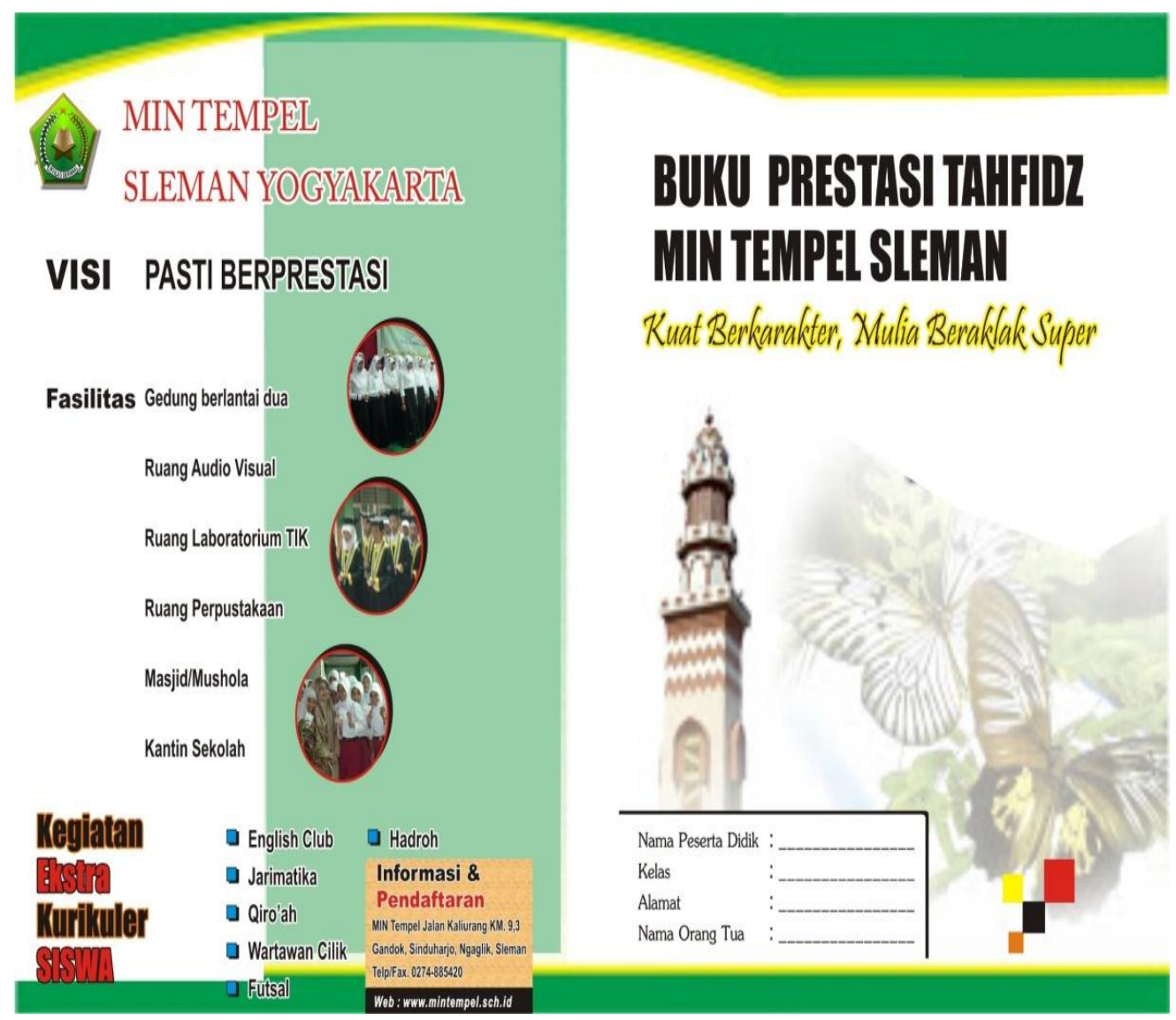

Gambar 3. Buku Prestasi Tahfidz

Semua siswa yang terlibat dalam kegiatam pembelajaran tahfidh Al-Qur'an dari kelas I hingga kelas IV diberi buku prestasi Tahfidh Al-Qur'an dari Madrasah yang bertujuan untuk mengukur tingkat efektivitas dan efisiensi program kelas tahfidh yang juga dapat dilihat dan dinilai oleh wali orang tua siswa masing-masing. Dalam buku prestasi Tahfidh ini berisi catatan perkembangan tahfidh dan catatan perkembangan bacaan siswa. Dari catatan tersebut dapat diketahui sejauh mana program kelas tahfidh ini berjalan baik dan optimal. 


\section{GATATAN PERKEMMBANGAN TAHFIDH}

\begin{tabular}{|c|c|c|c|c|c|c|c|}
\hline \multirow{3}{*}{ No } & \multirow{3}{*}{ HARI/TANGGAL } & \multirow{3}{*}{ SURAT } & \multirow{3}{*}{\begin{tabular}{|c|} 
HALAMAN \\
/AYAT \\
\end{tabular}} & \multirow{2}{*}{\multicolumn{2}{|c|}{ KETERANGAN }} & \multirow{3}{*}{ CATATAN } & \multirow{3}{*}{ PARAF } \\
\hline & & & & & & & \\
\hline & & & & LANJUT & ULANG & & \\
\hline \multicolumn{8}{|l|}{1} \\
\hline \multicolumn{8}{|l|}{2} \\
\hline \multicolumn{8}{|l|}{3} \\
\hline \multicolumn{8}{|l|}{4} \\
\hline 5 & & & & & & & \\
\hline
\end{tabular}

Catatan Ustadh/Dzah

Gambar 4. Catatan Perkembangan Tahfidh Siswa

\section{GATATAN PERKEMBANGAN BACAAN}

\begin{tabular}{|c|c|c|c|c|c|c|c|}
\hline \multicolumn{8}{|c|}{ EMBANGAN BACAAN } \\
\hline \multirow[t]{2}{*}{ No } & \multirow{2}{*}{ HARI/TANGGAL } & \multirow[t]{2}{*}{ IILID } & \multirow{2}{*}{$\begin{array}{l}\text { HALAMAN } \\
\text { /AYAT }\end{array}$} & \multicolumn{2}{|c|}{ KETERANGAN } & \multirow[t]{2}{*}{ CATATAN } & \multirow{2}{*}{ PARAF } \\
\hline & & & & LANJUT & ULANG & & \\
\hline 1 & & & & & & & \\
\hline 2 & & & & & & & \\
\hline 3 & & & & & & & \\
\hline 4 & & & & & & & \\
\hline 5 & & & & & & & \\
\hline
\end{tabular}

Catatan Ustadh/Dzah

Gambar 5. Catatan Perkembangan Bacaan Siswa 


\section{Kesimpulan}

Dari pembahasan di atas dapat disimpulkan bahwa dalam manajemen program kelas tahfidh meliputi perencanaan, pengorganisasian, pelaksanaan dan pengawasan. Pada tahap perancanaan meliputi : 1) Tujuan program kelas tahfidh Al-Qur'an, 2) Penentuan Materi Tahfidz Al-Qur'an, 3) Penentuan Alokasi Waktu dan Jam Pelajaran, 4) Membuat perangkat perencanaan. Pada tahap pengorganisasian meliputi Struktur Organisasi. Pada pelaksanaan meliputi target pencapaian kelas tahfidh Al-Qur'an, dan yang terakhir adalah pada pengawasan dibuat buku prestasi tahfiz Al-Qur'an yang meliputi catatan perkembangan tahfidh dan catatan perkembangan bacaan siswa.

\section{Daftar Pustaka}

Afifudin. (2009). Metodologi Penelitian Kualitatif. Bandung: CV. Pustaka Setia.

Aziz, A. R., (2004). Kiat Sukses Menjadi Hafidz Al-Qur'an Da'iyah. Bandung: PT Syamil Cipta Media

Majid, A. (2011). Perencanaan Pembelajaran: Mengembangkan Standar Kompetensi Guru. Bandung: Rosda Karya.

Margono. (2014). Metode Penelitian Pendidikan. Jakarta: Rineka Cipta.

Moleong, L. J., (2013). Metode Penelitian Kuantitatif. Bandung: PT Remaja Rosdakarya.

Mulyana, D. (2002). Metode Penelitian Kualitatif: Paradigma Baru Ilmu Komunikasi dan Ilmu Sosial Lainnya. Bandung: Remaja Rosdakarya.

Mulyasa. (2012). Manajemen Berbasis Madrasah. Bandung, Remaja Rosdakarya.

Nazaruddin. (2007). Manajemen Pembelajaran. Yogyakarta: Teras.

Robert, B. \& Steven, J. T., (1992). Pengantar Metoda Penelitian Kualitatif Suatu Pendekatan Fenomenologis Terhadap Ilmu-ilmu Sosial, terj. Arief Furchan, Surabaya: Usaha Nasional.

Sugiono. (2010). Memahami Penelitian Kualitatif. Bandung : Alfabeta.

Sugiono. (2015). Metode Penelitian Pendidikan: Pendekatan Kuantitatif, Kualitatif dan $R \& D$. Bandung: Alfabeta.

Suharsaputra, U. (2012). Metode Penelitian Kuantitatif, Kualitatif, dan Tindakan. Bandung: Refika Aditama

Syarifuddin. (2008). Efektivitas Kebijakan Pendidikan: Konsep, Strategi, Dan Aplikasi Kebijakan Menuju Organisasi Sekolah Efektif. Jakarta: Rineka Cipta.

Terry, G. R., \& Stephen G. F., (2003). Principles of Management. New Delhi: AITBS 
Yunus, M. (1990). Kamus Arab Indonesia. Jakarta: Hidakarya Agung.

Yunus, M. (2009). Kamus Arab Indonesia. Jakarta: Mahmud Yunus wa Dzurriyah.

Zaidin. (2015). Wawancara Pribadi, Yogyakarta Sembego: 14 Desember 2015 pukul 10.00 .

Ansori, I. (2018). Wawancara Pribadi, Yogyakarta: Jumat, 15 Mei 2018 pukul 13.30 WIB.

Isti. (2017). Wawancara pribadi, Yogyakarta: Sabtu, 16 Mei 2017, pukul 10.00 WIB.

Shofa, A. (2017). Wawancara pribadi, Yogyakarta: Sabtu, 18 Mei 2017, pukul 08.00 WIB. 